\title{
Effect of Different Sowing Methods on Growth, Yield and its Compo- nents of Wheat Under Intercropping Patterns with Egyptian Clover Var. Fahl
}

\author{
"El-Shamy, Moshira A. ${ }^{1}$; M.F. Seleiman" ${ }^{2}$ T.G. EL-Gaafary ${ }^{3}$ and H.Y.A. $\operatorname{Rady}^{3}$ \\ ${ }^{1}$ Crop intensification Res. Department, Field Crops Res. Institute, Agric. Res. Center, \\ Giza, Egypt. \\ ${ }^{2}$ Department of Crop Sciences, Faculty of Agriculture, Menoufia University, 32514 \\ Shibin El-kom, Egypt. \\ ${ }^{3}$ Forage crops Res. Department, Field Crops Res. Institute, Agric. Res. Center, Egypt. \\ "Corresponding author: moshiraahmed8@gmail.com
}

Received on: $24 / 4 / 2017$

Accepted for publication on: 4/5/2017

\begin{abstract}
One of the most important advantages of intercropping or sowing methods is to get the highest yield on a specified area of land through using more efficient way of the available resources. Two successive winter field experiments were conducted at Sakha Agricultural Research Station, Agricultural Research Center (A.R.C), Kafr El-Sheikh Governorate, Egypt, during 2014/2015 and 2015/2016 growing seasons in a split plot design with three replications to study the effects of three different sowing methods viz. flat, terraces and rows; main plots in addition to three different mixed intercropping treatments of Egyptian clover var. Fahl with wheat $(10,15$ and $20 \%$ of recommended seeding rate for Egyptian clover var. Fahl (i.e. $20 \mathrm{~kg} \mathrm{fed}^{-1}$ ) with $100 \%$ of recommended seeding rate of wheat [60 $\left.\mathrm{kg} \mathrm{fed}^{-1}\right]$; sub plots). In addition, the two crops were sown as pure stand cultivation in a flat sowing method. Results showed that sowing method of terraces and intercropping Egyptian clover var. Fahl by $10 \%$ with $100 \%$ wheat resulted in the highest improvement of growth and yield and its components in addition to the highest crude protein content in comparison to the other sowing methods and intercropping patterns. However, the pure stand of wheat had the highest values of grain yield fed $^{-1}$ and its components in comparison to intercropping treatments. The highest LER (land equivalent ratio; 1.30 and 1.29) and the highest total income (12034 and 11899 L.E.) were obtained when wheat was sown on terrace and intercropped with $10 \%$ of Egyptian clover var. Fahl in both of seasons, respectively. In conclusion, sowing method of wheat on terraces and intercropping $10 \%$ of Egyptian clover var. Fahl with wheat could be the appropriate suggestion for farmers in North Middle Nile Delta region, Egypt.
\end{abstract}

Keywords: Trifolium alexandrinum, Intercropping, Sowing method, Triticum aestivum, Productivity, Quality.

\section{Introduction}

Wheat (Triticum aestivum L.) is considered as a strategic cereal crop and as the main food for the Egyptians. The cultivated area of wheat in Egypt was 1.45 million fed in 1960 , while it was increased into 2.99 mil- lion fed in 2016 (USDA, 2017). The average productivity of wheat grains is about 2.7 ton $\mathrm{fed}^{-1}$, (Wheat Research Department, Field Crops Research Institute, Agricultural Research Center, Egypt), where the new high yielding wheat cultivars have 